\title{
Conversem, conversem!
}

Talk, talk!

\section{Heloísa Pait *}

Universidade Estadual Paulista Júlio de Mesquita Filho (UNESP) | São Paulo, Brasil hpait@marilia.unesp.br

Das irmãs de minha avó paterna conheci tia Tuba e tia Polinha apenas. Ouvi falar muito da tia Raquel, por intermédio de meu pai e de minha tia, para quem me parece ela foi figura presente, tanto pelo afeto como pelo exemplo. Uma médica. E também, um pouco menos, da tia Eva e da tia Branca, que fizeram família no Rio.

Minha avó, Fanny, conheci pouco. Íamos lá aos domingos e ela vinha em meus aniversários, ou de meu pai, que caíam no mesmo dia, solene, com um bolo espetacular carregados pelos filhos. Morreu idosa, quando eu já estava na faculdade. Nunca conversou comigo. Perguntei um dia ao meu irmão se algum dia a vó Fanny havia conversado com ele. Ele disse que não.

Sei dela como se sabe dos mortos: pelo que contam os outros. Sei que foi à Itália com meu bisavô, a mais velha das filhas. Sei que enviuvou cedo. Meu pai a adorava, minha mãe a detestava. Sei que seu professor admoestava os coleguinhas de escola: "a judiazinha sabe as respostas e vocês não." Sei que suspirava e se eu disser por que o fazia vou estar endossando o que um ou outro pensava dela. Só digo que era um suspiro descontente, entre a reclamação e a resignação. De qualquer forma, não fazíamos parte de seu mundo.

Já tia Polinha conhecemos melhor. Usava óculos com lentes grossas, e perguntava de nós. "Como vai a faculdade?", eu me lembro vividamente desse dia. Havia feito farmácia e trabalhado a vida toda. Vivia com a irmã e seus filhos solteiros, num arranjo condenado pela família, mas apenas da boca pra fora, pois era prático tanto que tia Polinha tivesse ajudado a criar os sobrinhos quanto que agora o tio Gilberto sustentasse mãe e tia. Eu, criança, não achava nada de mais, eram todos tios e moravam juntos. A casa era um pouco monótona, só isso.

Tia Polinha nos olhava com olhos fixos de míope, que não podem se dar ao luxo de flanar. "Come um ponzinho," ela insistia. “Um ponzinho, come." Ela tinha um sotaque forte ídiche, apesar de ter vindo criança para o Brasil, a mais nova das seis. Era amiga de minha avó materna, essa sim sempre presente, até o exagero, em nossas vidas, o que significava que era inteligente e também tolerante. Minha cunhada, que

* Professora na Universidade Estadual Paulista Júlio de Mesquita Filho e colaboradora do Estado da Arte, blog cultural do jornal O Estado de S. Paulo. 


\section{Arquivo Maaravi}

conheceu tia Polinha, é que disse: “Ai, vocês com seus Pait's eyes." Que são Pait's eyes? "Esse olhar fixo e perscrutador." Ah, entendi, como os da tia Polinha...

Queria que comêssemos e falássemos. Não me recordo de ela contar grandes histórias ou de fazer julgamentos sobre nós. Não nos analisava, como a tia Adélia, irmã de nossa avó materna, com seu saber psicanalítico e suas leituras francesas. Apenas perguntava coisas sobre nós. E insistia que comêssemos um pouco mais. É o que mais me lembro dela.

Um dia fomos visitar a família do Bom Retiro. Era uma festa. As crianças ficaram no quarto, pois a sala era pequena para todos. Minha prima Paula sentava ao meu lado, na cama, e tia Polinha numa cadeira em frente a nós. "Conversem."

Não sabíamos do que falar, não tínhamos crescido juntas. Éramos primas em segundo grau; Paula era neta da tia Tuba, que fazia os beigales mais espetaculares do mundo. Faço um parêntese. Esse mundo ídiche, de beigales e Bom Retiro, me era estranho. Meus pais eram militantemente modernos e tudo o que fosse além dos valores judaicos mais profundos era tido em casa como folclore, com o carinho e a condescendência que se têm com as coisas simples dos antigos.

Mas tínhamos boa vontade. Tentamos algumas frases. A conversa não engrenava. "Conversem, conversem." Tia Polinha insistia. Não sei se a Paula lembra desse dia. Temos em comum, nós duas, nossos enraizados valores judaicos que se traduzem em apreço extremado aos estudos e à família. Acredito que lembra, pois lembrar é parte de quem somos. Quando nos vemos, de qualquer modo, o espírito da tia Polinha está lá, nos dizendo que somos primas e que devemos conversar.

Mas não só lá. Quando entro em uma sala de aula, tia Polinha também está presente, os mesmos óculos, os mesmos olhos, as mesmas perguntas e o mesmo desconforto em, de repente, ter que falar com estranhos. Apenas por serem primos. Apenas por terem valores em comum. Conversem. Conversem.

Recebido em: 02/02/2018.

Aprovado em: 02/03/2018. 